\title{
Bacteriological Profile of Blood Culture of Patients from a Tertiary Care and Teaching Hospital of Banaskantha District, India
}

\author{
Radhika Khara*, Amar C. Sajjan, Anil Chaudhary and Aarushi Agrawal
}

Department of Microbiology, Banas Medical College and Research Institute At \& PostMoriya, Palanpur, Banaskantha, Gujarat -385001, India

*Corresponding author

\section{A B S T R A C T}

\section{Keywords}

Blood culture, bacteria, Candida species

Article Info

\section{Accepted:}

12 May 2021

Available Online:

10 June 2021
Blood culture remains a gold standard in establishing diagnosis of all blood stream infections as well as sepsis. Thus this study was aimed at isolating and identifying bacterial and/or fungal agents from blood culture of the patients admitted in the hospital. A total of 309 blood cultures were performed for a period of one year. A total of $74.43 \%$ (230/309) samples did not yield any bacterial/fungal growth whereas the rest $25.57 \%(79 / 309)$ showed growth with 79 isolates. All the samples yielded single isolates. Of the 79 isolates, $32.91 \%$ (26/79) were Gram negative bacilli, 56.96\% (45/79) were Gram positive bacteria and $10.12 \%(08 / 79)$ Candida species. Of the total isolates, Klebseilla spp. - 25.31\% (20/79) was the most frequent isolate from blood culture followed by CoNS - 22.78\% (18/79), Staphyloccoccus aureus - 16.45\% (13/79), MRCoNS - 20.82\% (09/79), Candida species $10.12 \%$ (08/79), MRSA $3.79 \%$ (03/79) and $2.53 \%(02 / 79)$ each of E. coli, Enterococcus species, Acinetobacter species and Pseudomonas spp.

\section{Introduction}

Culture of clinical samples has always been the best evidence to establish infection and is true in case of blood stream infections even (Nagoba, et al., 2005). Bacteria are a common cause of blood stream infections as well as sepsis around the world and blood culture helps to isolate these and identify them thus establishing the diagnosis. Gram negative sepsis predominates over gram positive sepsis and also the proportion of Candida species has considerably increased in many institutions due to prolonged treatment with multiple antibiotics, the use of indwelling intravascular devices, and prolonged neutropenia in patients with cancer have been demonstrated to be independent risk factors for the acquisition of 
nosocomial candidemia (Reinhart, et al., 2005)

This study was aimed at determining the bacteriological profile of blood cultures from patients in our setup. The objectives of this study were to perform blood culture obtained from patients and to isolate and identify the isolates obtained using standard biochemical tests.

\section{Materials and Methods}

This study was conducted in Microbiology Section of Central Laboratory under the Department of Microbiology for a period of one year.

A total of 309 samples were received for blood culture in the laboratory. These samples were sent from NICU, Paediatric Ward as well as Medicine Ward of the hospital.

Methods are described under the following headings: (Collee et al., 14 ${ }^{\text {th }}$ Ed.; Betty A. Forbes et al., $12^{\text {th }}$ Ed.; Koneman et al., $6^{\text {th }} \mathrm{Ed}$ )

\section{Collection}

For blood culture, blood samples were collected before administering antibiotics at our hospital. However, for patients referred from other hospitals, already treated with antibiotics, were still considered for blood culture and blood samples were collected before starting antibiotic in our setup.

Hence $5-7 \mathrm{ml}$ of blood sample was collected by venepuncture taking all aseptic precautions. For this a tourniquet was tied around the arm tightly and the patient was asked to make fist. The vein was palpated and located. Isopropyl alcohol $(70 \%)$ or Povidone Iodine (10\%) was applied with a help of sterile cotton over the cubital aspect of the forearm. Samples were collected in commercially available conventional Monophasic Brain Heart Infusion (BHI) Broth bottles (HiMedia-70ml broth for adults and $20 \mathrm{ml}$ for neonates and paediatric patients). Once received in the laboratory these were placed in incubator at $37^{\circ} \mathrm{C}$ for 24 hours before processing.

\section{Processing}

The subcultures were done on the second day of receiving the samples after an overnight incubation.

After the bottles were removed from incubator direct smears were prepared and stained by Gram stain to detect presence of organism in the bottles and the reports of the smears were communicated to the clinician as early as possible. Thereafter the samples were subcultured on Mac Conkey's agar, Blood agar and also on Saboraud's Dextrose Agar (SDA)(all media from HiMedia) if fungal elements were seen on direct smear. Inoculated plates were incubated for 18-24 hours at $37^{\circ} \mathrm{C}$. The plates were then observed for the formation of colonies. The blood culture bottles were again placed in the incubators.

After 24 hours if no growth was found on the plates, 2 more subcultures were done on alternate days i.e. a total of 3 subcultures were done before declaring culture as negative and reporting as "No organism isolated."

\section{Identification}

All plates showing growth were subjected to identification using standard methods. The colony characters were observed and utilised for identification. The gram stained smears from colonies were observed for presumptive identification of colonies as gram negative bacilli colonies or gram positive cocci colonies and to choose appropriate set of biochemical tests for their identification. 
For identification of gram positive cocci isolates, catalase, coagulase, mannitol salt agar test, were used whereas for gram negative isolates, catalase, oxidase, indole, methyl red, Voges-Proskauer, citrate, urease, motility, triple sugar iron test and sugar fermentation tests were carried out according to the standard methods. (Collee et al., 14 $\left.{ }^{\text {th }} \mathrm{Ed}\right)$ (Betty A. Forbes et al., 12 ${ }^{\text {th }} \mathrm{Ed}$ ) (Koneman et al., $6^{\text {th }}$ Ed) Methicillin resistance was detected as per the CLSI guidelines

\section{Results and Discussion}

A total of 309samples were received for blood culture from the patients of our setup. Of the total 309 patients, $58.57 \%$ (181/309) were male and $41.42 \%(128 / 309)$ were female patients. A total of 309 blood cultures were performed during a period of one year. Of the total 309 blood samples cultured, $74.43 \%$ (230/309) samples did not yield any bacterial/fungal growth whereas the rest $25.57 \%(79 / 309)$ showed growth as shown in Chart 1.

A total of 79 isolates were obtained from 79 blood culture positive samples as all the samples yielded only single isolates.

Of the 79 isolates, $56.96 \%$ (45/79) were Gram positive bacteria/cocci were predominant followed by32.91\% (26/79) Gram negative bacilli and 10.12\% (08/79) Candida species. Though gram positive cocci were predominant, Klebseilla spp. - 25.31\% (20/79) was the most frequent isolate from blood culture followed by CoNS - 22.78\% (18/79), Staphyloccoccus aureus - 16.45\% (13/79), MRCoNS - 20.82\% (09/79), Candida species $10.12 \%(08 / 79)$, MRSA $3.79 \%(03 / 79)$ and $2.53 \%$ i.e. 02 of each of E. coli, Enterococcus species,, Acineto bacter species and Pseudomonas spp.(Chart 2)

Culture positive findings $(25.57 .0 \%)$ of our study, when compared to studies from other regions of India, are higher (Table 1). This could be because of the proper sample collection and timely and proper processing of the samples.

Gram positive bacteria predominated over Gram negative and these findings are comparable to those with Lee et al., 2007 and Kumalo, et al., 2016 who reported Gram positive cocci predominance with $52.33 \%$ and $53.3 \%$ respectively but contrasting findings have been reported by other studies (Saravu, et al., 2015; Divatia, et al., 2016; Kante, et al., 2014; Sahoo, et al., 2016; Gupta, et al., 2016; Sonawane, et al., 2016; Oza, et al., 2016; Jacob, et al., 2009).

Despite the predominance of gram positive cocci in our study Klebseilla spp. was the most frequent isolate from blood culture followed by CoNS, Staphyloccoccus aureus, and MRCONS. These findings are similar to Gupta S et al., 2016) and Sonawane J et al., 2016. Whereas in the other studies, Klebsiella pneumonia (Oza, et al., 2016), Staphylococcus aureus (Lee et al., 2007 \& Kumalo, et al., 2016), E. coli (Sahoo, et al., 2016; Gupta S et al., 2016) and non-typhoidal Salmonella (Jacob, et al., 2009) have been reported as the most frequent isolates from blood culture samples.

CoNS was the second most common blood culture isolate i.e. $(n=18+9=27) 34.17 \%$ as well as the most common gram positive cocci including MRCoNS (which was $33.33 \%$ of the total CoNS). 
Table.1 Comparison of blood culture outcomes and isolate types with other studies

\begin{tabular}{|c|c|c|c|}
\hline Author & Place & $\begin{array}{c}\text { Positive Blood } \\
\text { Culture Outcome (\%) } \\
\text { \& Isolate types }(\%)\end{array}$ & Frequent Isolates (\%) \\
\hline $\begin{array}{c}\text { Kante Meenakshi et } \\
\text { al., } 2014 .\end{array}$ & $\begin{array}{l}\text { Andhra Pradesh, South } \\
\text { India }\end{array}$ & $\begin{array}{c}\text { Outcome }-17 \% \\
\text { Gram negative }-23 / 34 \\
(67.64 \%) \\
\text { Gram positive }-11 / 34 \\
(32.36 \%)\end{array}$ & $\begin{array}{c}\text { Pseudomonas aeruginosa } \\
(6.6 \%) \\
\text { S. aureus }(4.5 \%) \\
\text { Acinetobacter spp. }(6.6 \%) \\
\text { Klebsiella pneumoniae }(2 \%) \\
\text { CoNS }(1 \%)\end{array}$ \\
\hline Sahoo, et al., 2016. & Odisha, East India & $\begin{array}{c}\text { Outcome -26\% } \\
\text { Gram negative - } \\
69.23 \% \\
\text { Gram positive - } \\
30.76 \%\end{array}$ & $\begin{array}{c}\text { E. coli }(34.6 \%) \\
\text { Klebsiella spp. }(26.9 \%) \\
\text { S. aureus }(23.1 \%) \\
\text { A. baumanii }(7.7 \%) \\
\text { CoNS }(7.7 \%)\end{array}$ \\
\hline Gupta, et al., 2016. & New Delhi, North India & $\begin{array}{c}\text { Outcome - } 16.5 \% \\
\text { Gram negative - } \\
58.34 \% \\
\text { Gram positive - } \\
41.65 \%\end{array}$ & $\begin{array}{c}\text { E. coli }(22.4 \%) \\
\text { Klebsiella spp. }(19.7 \%) \\
\text { S. aurues }(18.3 \%) \\
\text { CoNS }(17.4 \%) \\
\text { Pseudomonas spp. }(8.40 \%) \\
\text { Acinetobacter spp. }(5.20 \%) \\
\text { Enterococcus spp. }(4.8 \%) \\
\text { Streptococcus spp. }(4.8 \%) \\
\text { S. typhi }(1 \%) \\
\text { Citrobacter spp. }(0.9 \%) \\
\text { Proteus spp. }(0.35 \%)\end{array}$ \\
\hline Sonawane, et al., 2016. & $\begin{array}{l}\text { Navi Mumbai, West } \\
\text { India }\end{array}$ & $\begin{array}{c}\text { Outcome } 10.29 \% \\
\text { Gram negative - } \\
83.22 \% \\
\text { Gram positive - } \\
16.78 \%\end{array}$ & $\begin{array}{c}\text { Klebsiella spp. }(22.38 \%) \\
\text { Pseudomonas spp. }(20.98 \%) \\
\text { Acinetobacter spp. }(17.48 \%) \\
\text { E. coli }(11.19 \%) \\
\text { S. typhi }(7.70 \%) \\
\text { Enterococcus spp. }(7.70 \%) \\
\text { S. aureus }(6.99 \%) \\
\text { Enterobacter spp. }(3.50 \%) \\
\text { Strep. spp. }(2.10 \%)\end{array}$ \\
\hline Oza, et al., 2016. & Surendranagar, Gujarat & $\begin{array}{c}\text { Outcome } 18.62 \% \\
\text { Gram negative - } \\
67.40 \% \\
\text { Gram positive - } \\
32.60 \%\end{array}$ & $\begin{array}{c}\text { K. pneumoniae }(34.78 \%) \\
\text { CoNS }(15.22 \%) \\
\text { Pseudomonas spp. }(10.87 \%) \\
\text { E. coli }(8.69 \%) \\
\text { S. typhi }(4.35 \%) \\
\text { Enterococcus spp. }(4.35 \%) \\
\text { Acinetobacter spp. }(4.35 \%) \\
\text { Unidentified GNB }(4.35 \%) \\
\text { Strep. spp. }(2.17 \%)\end{array}$ \\
\hline Sundarmono, et al., & South East Asia Region & Outcome $12 \%$ (in & E. $\operatorname{coli}(5 \%)$ \\
\hline
\end{tabular}




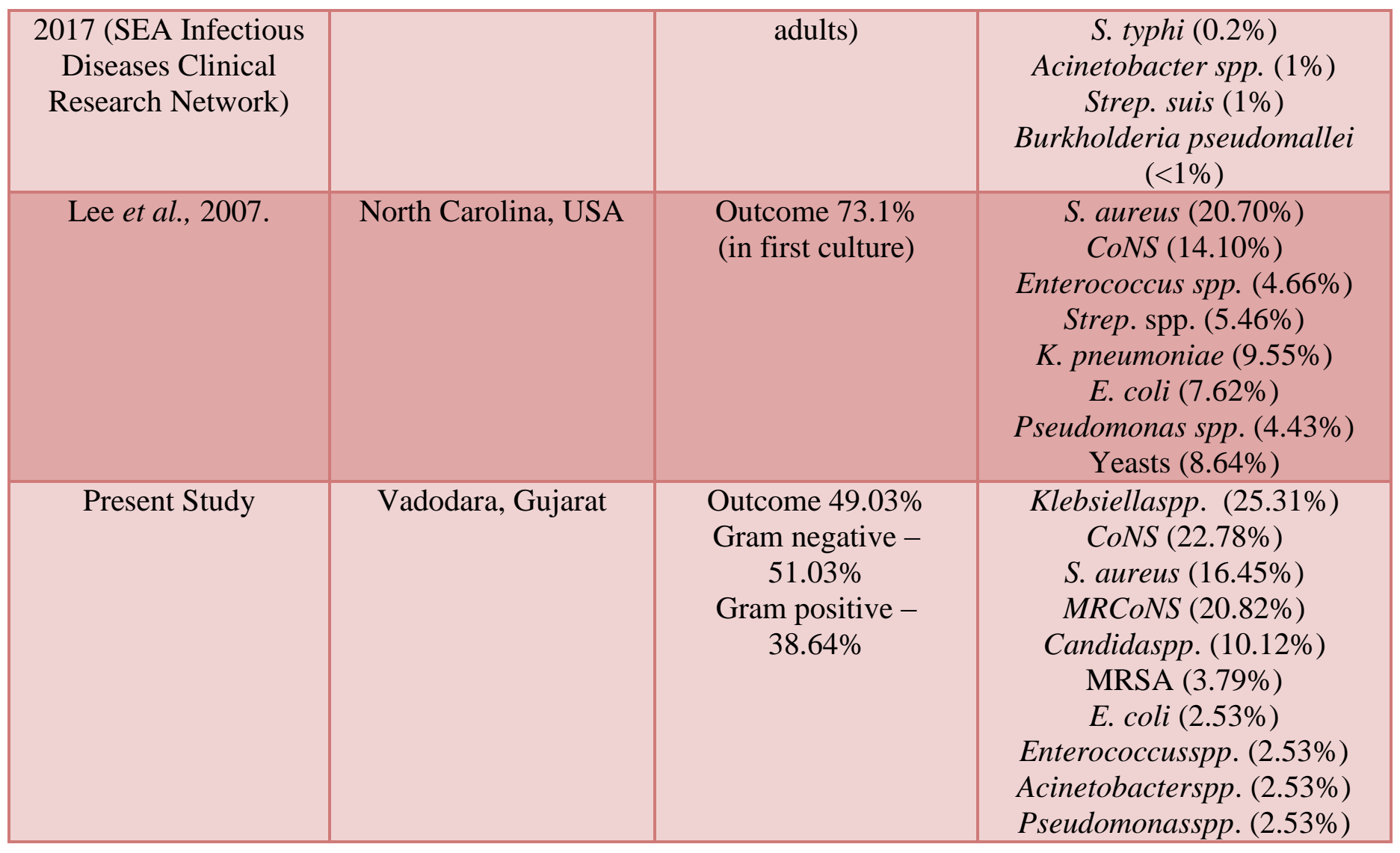

Chart.1 Blood Culture Outcome (N=309)

\section{Blood Culture Outcome ( $\mathrm{N}=309)$}

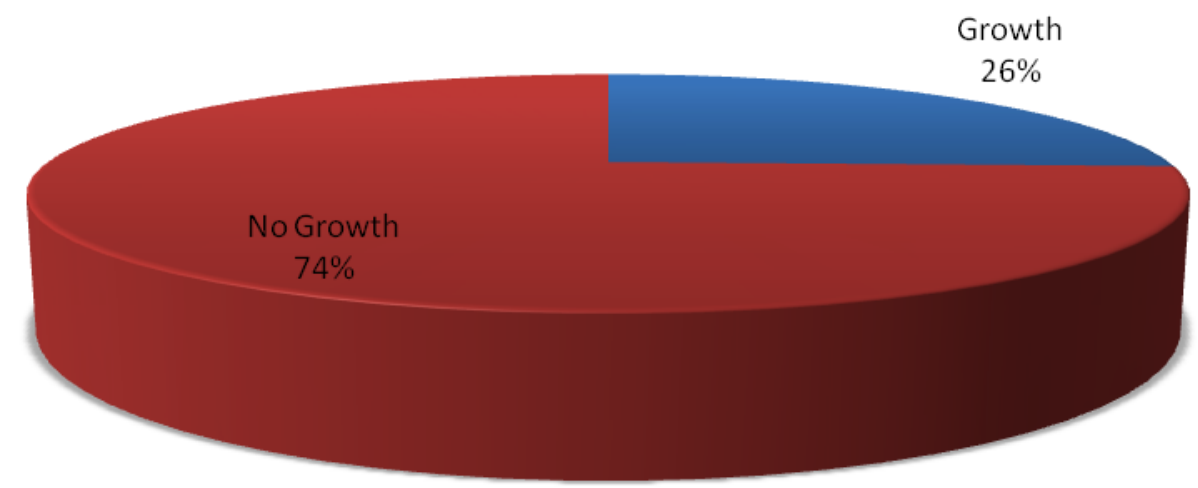




\section{Chart.2 Isolate types}

\section{Isolate Type}

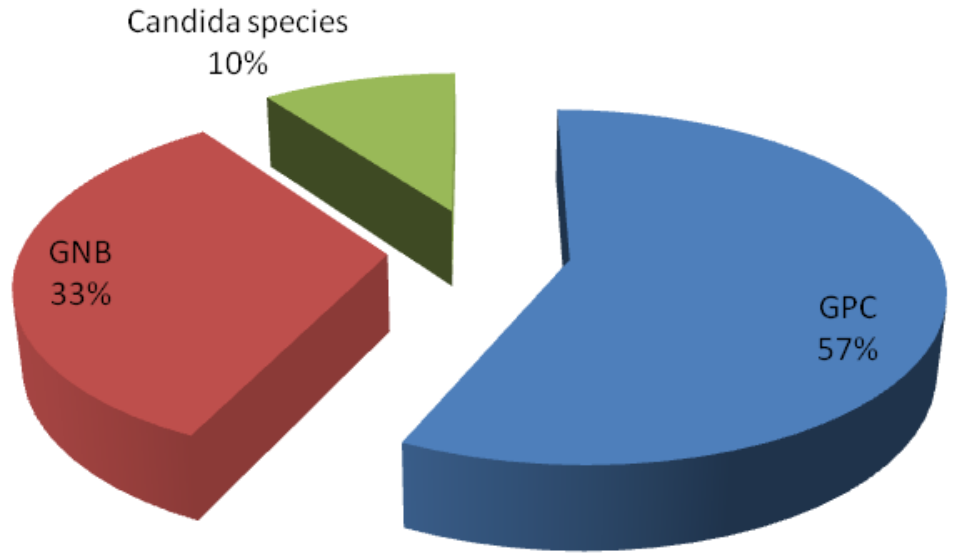

Chart.3 Number \& Type of Blood Culture Isolates obtained

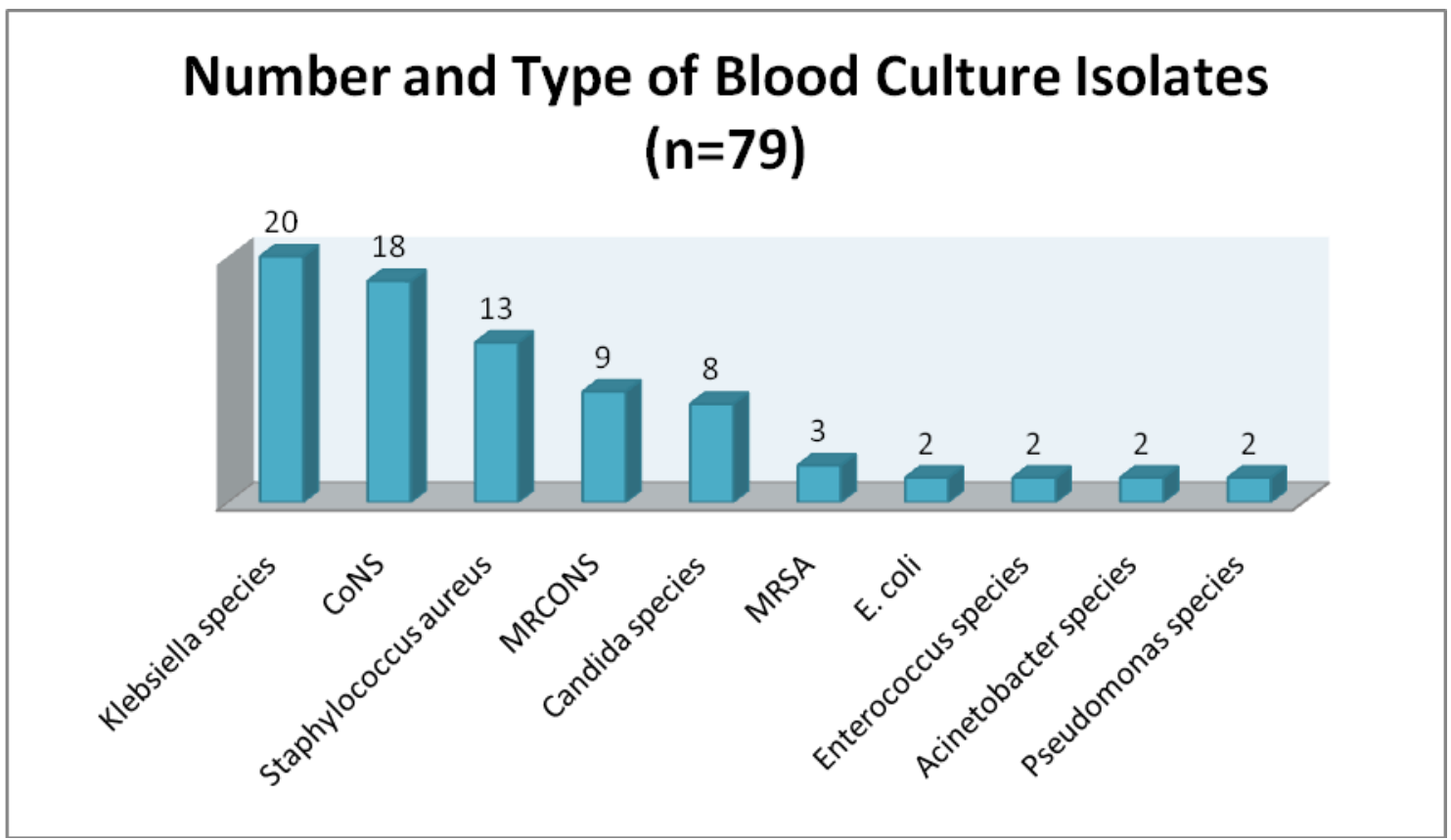

Most of the studies consider it as a contaminant (Sudarmono, et al., 2017) but as these have been isolated from critically ill patients admitted in the hospital these isolates were considered to be pathogenic rather than contamination. Singh et al., 2016 used correlation with clinical parameters like temperature $>38^{\circ} \mathrm{C}$ or $<36^{\circ} \mathrm{C}$, systolic blood pressure of $<90 \mathrm{~mm} / \mathrm{Hg}$, total leukocyte count $>12,000 / \mu 1$ or $<4000 / \mu 1$ and presence of $>10 \%$ immature bands for establishing the significance of CoNS isolated from single 
cultures. Also Oza, et al., 2016 and Kumalo, et al., 2016 report $13.3 \%$ CoNS being the second most common isolates from blood culture. Kumalo, et al., 2016 suggests that though in past they were considered as nonpathogenic but currently due to increased use of indwelling medical devices they are on the rise.

Blood culture is a very useful in establishing infections of blood stream and sepsis. It is important to know the type of bacteria responsible for the infection as it helps to know the pathogenesis and helps clinicians choose right treatment when antimicrobial susceptibility results are made available to them and also ways to prevent infections due to such microbes from spreading in the hospital.

Overall the gram positive bacteria were commonly found as the cause of blood stream infections in our setup with Klebsiella spp. been the most common isolate and amongst gram positive cocci CoNS \& Staphylococcus aureus were the most common isolates followed by Candida species. The other bacteria like E. coli, Enterococcus species, Acinetobacter species and Pseudomonas species, though isolated in smaller percentage, yet they were found to be important cause of infection in blood which can lead to condition like sepsis.

\section{References}

Betty, A., Forbes, Daniel, F., Sahm, Alice, S., Weissfeld. Bailey \& Scott's Diagnostic Microbiology. 12lh Ed, 216-247

Collee, J. G., Fraser, A. G., Marmion, B. P., Simmons, A. Mackie and McCartney Practical Medical Microbiology. 14th Ed.

Divatia J V, Amin P R, Ramakrishnan N, Kapadia F N, Todi S, Sahu S, et al., including all INDICAPS Study
Investigators. 2016. Intensive Care in India: The Indian Intensive Care Case Mix and Practice Patterns Study. Indian J Crit Care Med [serial online], 20:216

Gupta S, Kashyap B. 2016. Bacteriological profile and antibiogram of blood culture isolates from a tertiary care hospital of North India. Trop J Med Res;19:94-9.

Jacob S T, Moore C C, Banura P, Pinkerton R, Meya D, et al., (2009) Severe Sepsis in Two Ugandan Hospitals: a Prospective Observational Study of Management and Outcomes in A Predominantly HIV-1 Infected Population. PLoS ONE 4(11):e7782.

Kante M, Uma P, John MS, Naidu MP. 2014. Bacterial profile of blood stream infections and antibiotic susceptibility pattern of isolates. Int J Curr Microbiol App Sci, 3(12): 222-233.

Kumalo A, Kassa T, Mariam Z S, Daka D and Tadesse A H.2016. Bacterial Profile of Adult Sepsis and their antimicrobial Susceptibility Pattern at Jimma University Specialized Hospital, South West Ethiopia. Health Science J; 10 (2):

Lee A, Mirrett S, Reller L B, Weinstein M P. 2007. Detection of bloodstream infections in adults: How many blood cultures are needed? J Clin Microbiol;45:3546-8.

Nagoba B S. 2005. Clinical Microbiology. First Edition, BI Publications Pvt. Ltd

Oza S S, Mehta S J, Kikani K M, Oza S G. 2016. Bacteriological profile and antibiogram of blood culture isolates from patients of rural tertiary care hospital. Indian J Microbiology \& Mycology; 4 (3):1-7.

Sahoo D, Mohanty L, Panda S S, Mishra S N. 2016. Bacteriological analysis of blood culture isolates in patients with sepsis in a tertiary care hospital of eastern 
India. International Journal of Contemporary Medical Research 2016;3(12):3448-3450.

Saravu K, Prasad M, Eshwara V K, Mukhopadhyay C. 2015. Clinicomirobiological profile and outcomes of nosocomial sepsis in an Indian tertiary care hospital - a prospective cohort study. Pathogens and Global Health; 109(5): 228-235.

Sonawane J, Kamnath N, Shetty K, Swaminathan R. 2016. Bacteriological Profile and Antimicrobial Susceptibility Testing of Blood Culture Isolates from a Tertiary Care Hospital,
Navi Mumbai. JMSCR; 4 (10): 1311613124.

Sudarmono P, Aman A T, Arif M, Syarif A K, Kosasih H, Karyana M et al., 2017. Causes and outcomes of sepsis in South East Asia: a multinational and multicentre cross-sectional study by South East Asia Infectious Diseases Research Network. Lancet Global Health; 5: e157-67. Winn W, Allen S, Janda W, Koneman E, Procop G, Schreckenberger P, et al., 2006. Koneman's Colour Atlas \& Textbook of Diagnostic Microbiology, $6^{\text {th }}$ Edition.

\section{How to cite this article:}

Radhika Khara, Amar C. Sajjan, Anil Chaudhary and Aarushi Agrawal. 2021. Bacteriological Profile of Blood Culture of Patients from A Tertiary Care and Teaching Hospital of Banaskantha District, India. Int.J.Curr.Microbiol.App.Sci. 10(06): 407-414.

doi: https://doi.org/10.20546/ijcmas.2021.1006.043 